\title{
Pharmaceutical Nanocarriers (Liposomes and Micelles) in Cancer Therapy
}

\section{Onkar S. Vaze*}

100 Corporate Drive, South Plainfield, New Jersey, U.S.A., 07080

\section{Editorial}

Fundamental progress in cancer biology has resulted in remarkable advances in diagnosis and cancer therapy. The need now is to transform this knowledge into effective therapies. The effectiveness of chemotherapeutic drugs is severely limited due to the dose-limiting toxicity and patient morbidity. In cancer therapy, effective delivery of the drug to the tumor site while avoiding off-site side effects is the primary challenge. This challenge can be overcome by targeting the tumor site selectively to avoid the undesired side-effects at non-target sites after the systemic delivery. A good drug delivery system fulfills several pharmaceutical requirements including increase in therapeutic effect, good biocompatibility, an ability to accumulate at a targeted site and controlled release of the drug at the target site [1]. Nanocarriers assisted delivery of drugs has become a successful strategy that enhances the delivery of small molecule and large molecules such a genes and peptides or proteins [2]. Different nanocarriers such as nanospheres, nanocapsules, liposomes, micelles, dendrimers, quantum dots, solid lipid nanoparticles, polymeric nanoparticles, gold nanoparticles, virus and virus-like nanoparticles have been explored for the delivery of small molecules and large molecules therapeutics.

Liposomes and micelles are the most extensively studied and understood pharmaceutical nanocarriers. Cholesterol and phospholipid molecules, that normally form cell membranes, generate liposomes which are vesicular nanostructures. Therapeutic liposomes are 50-200 $\mathrm{nm}$ in size and can be loaded with water soluble therapeutic agents in the aqueous core and water insoluble therapeutic agents in phospholipid (hydrophobic) bilayer. Micelles are colloidal dispersion with a particle size between 5-100 nm. For pharmaceuticals with poor solubility, Micelles can improve the bioavailability and solubility. Therapeutic agents in conjunction with nanocarriers such as liposomes and micelles result in better pharmacokinetic properties of the carrier-loaded drugs thereby improving therapeutic activity. These systems provide easier control, composition, size and in vivo stability in comparison with other drug delivery systems [3]. Furthermore, preparation is considerably simpler and also small amounts of a targeting component can be attached to a these pharmaceutical nanocarriers. Thus, the fundamentals of liposomal and micellar nanocarrier and their biological interactions are well studied, and aids to design such nanocarriers with specific drug delivery, targeting and release characteristics. Lipid-or polymer-based delivery of therapeutic agent is the basic and simple nanotechnology platform which has found the most success in the clinics (Table 1).

Although an extensive number of scientific publications regarding these pharmaceutical nanocarriers exist, the translation of these pharmaceutical nanocarriers has been slow in comparison to that for small molecule drugs [4]. Lack of clear regulatory guidelines as well as technical issues are factors limiting the clinical application of nanomedicines [5].

As opposed to conventional drugs, the development of these technologies (nanomedicine/nanocarriers) combine expert knowledge from the fields of Chemistry, Biology and Physics. The products of these collaborations are wide ranging in concept and design. This conjunction of various academic disciplines in addition to a concerted effort by regulatory bodies and industry is required for advances in such technologies. With these stakeholders working in harmony, it is possible to steer future research to obtain nanomedicine products that are both effective and safe.

Pharmaceutical nanocarriers such as liposomes and micelles have the potential to create new sources of revenue for the pharmaceutical and biotech industries and will improve the life cycle of proprietary drugs [6]. It will revolutionize the field of medicine by creating new therapies. So far, academic departments, new startups and small technology companies seem to have invested more effort in such technologies [614]. Drug delivery has already been revolutionized by nanotechnology. Pharmaceutical nanocarriers have made significant contributions to medicine and diagnostics and it will further continue to revolutionize these fields and further investigations are warranted in this area.

\begin{tabular}{|c|c|c|c|c|c|}
\hline $\begin{array}{c}\text { Pharmaceutical } \\
\text { nanocarriers }\end{array}$ & $\begin{array}{l}\text { Tradel } \\
\text { Product } \\
\text { Name }\end{array}$ & Drug & Company & $\begin{array}{l}\text { Current } \\
\text { Status }\end{array}$ & Ref \\
\hline \multirow{5}{*}{ Liposomes } & Onivyde & Irinotecan & $\begin{array}{c}\text { Merrimack } \\
\text { Pharmaceuticals }\end{array}$ & $\begin{array}{c}\text { Approved } \\
\text { in October } \\
2015\end{array}$ & 14 \\
\hline & Maroqbio & $\begin{array}{l}\text { Vincristine } \\
\text { sulfate }\end{array}$ & $\begin{array}{c}\text { Spectrum } \\
\text { Pharamceuticals }\end{array}$ & $\begin{array}{c}\text { Approved } \\
\text { in October } \\
2012\end{array}$ & 12 \\
\hline & Doxil & Doxorubicin & Janssen Biotech & $\begin{array}{l}\text { Approved } \\
\text { in } 1995\end{array}$ & 7 \\
\hline & Mepact & Mifamurtide & $\begin{array}{c}\text { Takeda } \\
\text { Pharmaceuticals }\end{array}$ & $\begin{array}{l}\text { Phase III } \\
\text { (USA) } \\
\text { Approved } \\
\text { in Europe }\end{array}$ & 9 \\
\hline & $\begin{array}{l}\text { ALN- } \\
\text { VSP02 }\end{array}$ & $\begin{array}{c}\text { siRNA } \\
\text { against } \\
\text { VEGF and } \\
\text { kinesin } \\
\text { spindle } \\
\text { protein }\end{array}$ & $\begin{array}{c}\text { Alnylam } \\
\text { Pharmaceuticals }\end{array}$ & Phase I & 8 \\
\hline \multirow{5}{*}{ Micelles } & $\begin{array}{l}\text { Genexol- } \\
\text { PM }\end{array}$ & Paclitaxel & $\begin{array}{l}\text { Samyang } \\
\text { Biopharma }\end{array}$ & $\begin{array}{c}\text { Approved } \\
\text { (South } \\
\text { Korea) } \\
\text { Phase II } \\
\text { (USA) }\end{array}$ & 7 \\
\hline & Paclical & Paclitaxel & $\begin{array}{c}\text { Osamnia } \\
\text { Pharamceutical }\end{array}$ & Phase III & 13 \\
\hline & NC 6004 & Cisplatin & Nanocarrier & Phase II & 10 \\
\hline & NK012 & SN-38 & $\begin{array}{l}\text { Nippon Kayaku } \\
\text { Co. Ltd }\end{array}$ & Phase II & 11 \\
\hline & SP1049C & Doxorubicin & $\begin{array}{c}\text { Supratek } \\
\text { Pharmaceuticals }\end{array}$ & Phase II & 7 \\
\hline
\end{tabular}

Table 1: Selected list of nanomedicines in oncology.

*Corresponding authors: Vaze OS, 100 Corporate Drive, South Plainfield, NJ 08863, USA, Tel: $19089129255 ;$ E-mail: onkarvaze@gmail.com

Received May 03, 2016; Accepted May 05, 2016; Published May 12, 2016

Citation: Vaze OS (2016) Pharmaceutical Nanocarriers (Liposomes and Micelles) in Cancer Therapy. J Nanomed Nanotechnol 7: e138. doi:10.4172/21577439.1000e138

Copyright: @ 2016 Vaze OS. This is an open-access article distributed under the terms of the Creative Commons Attribution License, which permits unrestricted use, distribution, and reproduction in any medium, provided the original author and source are credited. 
Citation: Vaze OS (2016) Pharmaceutical Nanocarriers (Liposomes and Micelles) in Cancer Therapy. J Nanomed Nanotechnol 7: e138. doi:10.4172/2157-7439.1000e138

Page 2 of 2

\section{References}

1. Carstens MG, Rijcken CJF, van Nostrum CF, Hennink WE (2008)Pharmaceutical Micelles: Combining Longevity, Stability, and Stimuli Sensitivity. Multifunctional Pharmaceutical Nanocarriers. Springer NewYork, USA.

2. Magadala P, van Vlerken LE, Shahiwala A, Amiji MM (2008) Multifunctional Polymeric Nanosystems for Tumor-Targeted Delivery. Multifunctional Pharmaceutical Nanocarriers, V Springer Newyork, USA.

3. Torchilin VP (2006) Lipid-Based Parenteral Drug Delivery Systems: Biologica Implications, in Role of Lipid Excipients in Modifying Oral and Parenteral Drug Delivery. John Wiley and Sons 48-87.

4. Venditto VJ, Szoka FC Jr (2013) Cancer nanomedicines: so many papers and so few drugs! Adv Drug Deliv Rev 65: 80-88.

5. Bregoli L, Movia D, Gavigan-Imedio JD, Lysaght J, Reynolds J, et al. (2016) Nanomedicine applied to translational oncology: A future perspective on cancer treatment. Nanomedicine 12: 81-103.

6. Brown PD, Patel PR (2015) Nanomedicine: a pharma perspective. Wiley Interdiscip Rev Nanomed Nanobiotechnol 7: 125-130.

7. Heidel JD, Davis ME (2011) Clinical developments in nanotechnology for cancer therapy. Pharm Res 28: 187-199.
8. Wang AZ, Langer R, Farokhzad OC (2012) Nanoparticle delivery of cancer drugs. Annu Rev Med 63: 185-198.

9. Anderson PM, Tomaras M, McConnell K (2010) Mifamurtide in osteosarcoma-a practical review. Drugs Today (Barc) 46: 327-337.

10. Plummer R, Wilson RH, Calvert H, Boddy AV, Griffin M, et al. (2011) A Phase I clinical study of cisplatin-incorporated polymeric micelles (NC-6004) in patients with solid tumours. Br J Cancer 104: 593-598.

11. Hamaguchi T, Doi T, Eguchi-Nakajima T, Kato K, Yamada Y, et al. (2010) Phase I study of NK012, a novel SN-38-incorporating micellar nanoparticle, in adult patients with solid tumors. Clin Cancer Res 16: 5058-5066.

12. Rodriguez MA, Pytlik R, Kozak T, Chhanabhai M, Gascoyne R, et al. (2009) Vincristine sulfate liposomes injection (Marqibo) in heavily pretreated patients with refractory aggressive non-Hodgkin lymphoma: report of the pivotal phase 2 study. Cancer 115: 3475-3482.

13. Egusquiaguirre SP, Igartua M, Hernández RM, Pedraz JL (2012) Nanoparticle delivery systems for cancer therapy: advances in clinical and preclinical research. Clin TransI Oncol 14: 83-93.

14. Bates SE, Fojo T (2016) Clinical trials: New drug for pancreatic cancer highlights the dual effect of regulatory approvals. Nat Rev Clin Oncol 13: 205-206. 